dye for mammalian cells in monolayer culture. J. Histochem. Cytochem. 32:1084-1090.

4.Pappenheimer, A.M. 1917. Experimental studies upon lymphocytes: I. The reactions of lymphocytes under various experimental conditions. J. Exp. Med. 25:633.

5.Patterson, M.K. 1979. Measurement of growth and viability of cells in culture. Methods Enzymol. 58:141.

6.Phillips, H.J. 1973. Dye exclusion tests for cell viability, p. 406-408. In P.F. Kruse Jr. and M.K. Patterson Jr. (Eds.), Tissue Culture: Methods and Applications. Academic Press, New York

These studies were funded in part by NIH Grant PO1 NS31492-01 (to H.A.G. and L.G.E.) and a generous grant from the Charles A. Dana Foundation (to H.A.G. and L.G.E.). Address correspondence to Harris A. Gelbard, University of Rochester Medical Center, Box 631, 601 Elmwood Avenue, Rochester, NY 14642, USA. Internet: hgelbard@mail.neurology.rochester.edu

Received 25 June 1996; accepted 2 December 1996.

Seth W. Perry, Leon G. Epstein and Harris A. Gelbard University of Rochester Medical Center

Rochester, NY, USA

\section{Detection of Specific DNA-Binding Protein in HeLa Whole-Cell Extract}

BioTechniques 22:1024-1026 (June 1997)

DNA-binding proteins play a very important role in cellular processes such as replication, DNA recombination, transcription and gene regulation. The advent of molecular biology has greatly enhanced ability in the detection, isolation and characterization of these proteins. Many methods, including gel mobility shift assay (GMSA), UV cross-linking, DNase footprinting, methylation and uracil interference assay, have been successfully used in the study of DNA-binding proteins. Silva et al. (3) reported a method known as Southwestern hybridization, in which proteins are resolved on a sodium dodecyl sulfate (SDS) polyacrylamide gel and transferred onto nitrocellulose. Transferred proteins are subjected to hybridization using a uniformly ${ }^{32} \mathrm{P}-\mathrm{la}-$ beled DNA probe. The use of this method has greatly enhanced the detection sensitivity of DNA-protein interaction. However, the transfer of proteins onto a nitrocellulose membrane inevitably causes some protein loss, which can be detrimental to detection, especially when such protein has a low concentration. We report a simplified Southwestern analysis that produces comparable resolution but greatly shortens the experimental time and eliminates protein loss during protein transfer.

The adenovirus type 2 (Ad2) E1A upstream regulatory sequence (URS) contains an element that is regulated by 12-o-tetradecanoyl-phorbol-13-acetate (TPA), a phorbol ester (1). In an effort to identify TPA-inducible proteins that are able to bind to Ad2 E1A URS, we used Southwestern analysis. HeLa whole-cell extract was prepared as described by Manley et al. (2). Fifty micrograms of cell extract were resolved by $8 \%$ SDS polyacrylamide gel electrophoresis (PAGE). The gel was incubated in $200 \mathrm{~mL}$ renaturation buffer $(50 \mathrm{mM} \mathrm{NaCl}, 10 \mathrm{mM}$ Tris, $\mathrm{pH}$ 7.4, 2 mM EDTA, $0.1 \mathrm{mM}$ dithiothreitol [DTT] and $4 \mathrm{M}$ urea) with gentle agitation for $3 \mathrm{~h}$ at room temperature (or at $4^{\circ} \mathrm{C}$ for $18 \mathrm{~h}$ ). Then the gel was incubated in $200 \mathrm{~mL}$ of blocking buffer $\mathrm{H}(10 \mathrm{mM}$ Tris, $\mathrm{pH} 8.0,2 \mathrm{mM} \mathrm{MgCl}$, $1 \mathrm{mM}$ mercaptoethanol, $50 \mathrm{mM}$ of $\mathrm{NaCl}$ and 5\% Carnation ${ }^{\circledR}$ nonfat dry milk) for $2 \mathrm{~h}$ with gentle agitation at room temperature. A uniformly ${ }^{32} \mathrm{P}-1 \mathrm{a}-$ beled polymerase chain reaction (PCR) fragment of Ad2 E1A URS (nucleotide [nt] -240 to -160$)$ and $10 \mathrm{mg} / \mathrm{mL}$ of sonicated salmon sperm DNA fragments were added as nonspecific competitor to the blocking buffer and incubated for $3 \mathrm{~h}$ at room temperature. After hybridization, the gel was washed three times with buffer $\mathrm{H}$ for 10 min each. The gel was vacuum-dried and subjected to autoradiography for $16 \mathrm{~h}$. The results (Figure 1) show that a 20$\mathrm{kDa}$ protein (lane 2) binds specifically to Ad2 E1A URS at nt -240 to -160 in TPA-treated HeLa cells. While in control-cell extract (lane 1), a 45-kDa protein binds specifically to the same Ad2 E1A URS region. The same gel was stained with Coomassie ${ }^{\circledR}$ blue and showed that equal amounts of protein extract were loaded in each lane (data not shown).

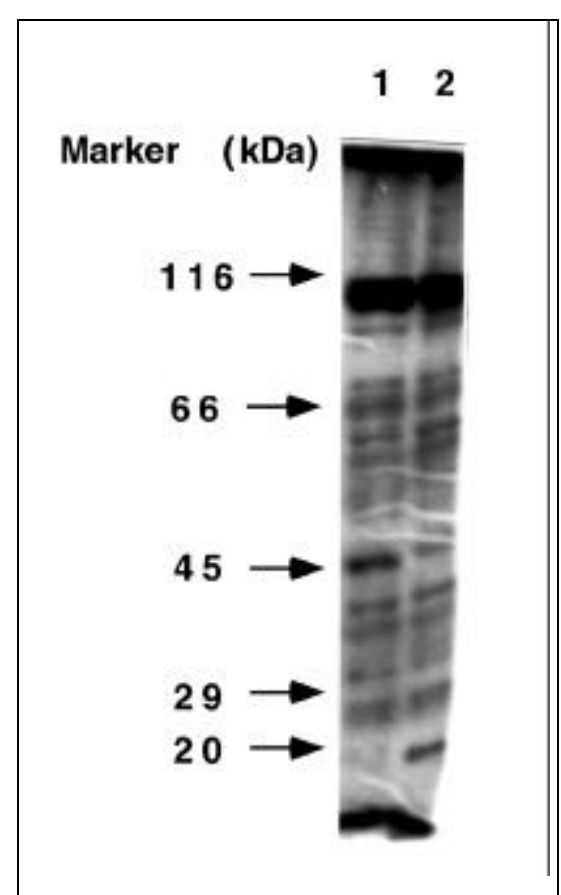

Figure 1. In vitro DNA-protein hybridization using a uniformly PCR-labeled Ad2 E1A URS probe and HeLa whole-cell extract. Lane 1: dimethyl sulfoxide (DMSO)-treated cell extract; lane 2: TPA-treated cell extract. 
The modification to the Southwestern analysis is advantageous because it omits the protein transfer procedure that inevitably causes some protein loss, and electrotransfer of proteins to nitrocellulose membranes from polyacrylamide gels is not $100 \%$ efficient. This was confirmed by silver staining of the polyacrylamide gel after electrotransfer of proteins (data not shown). Also, the sensitivity is higher compared to GMSA because the probe used is uniformly labeled by PCR. Thus, this method combines the advantages of DNA-protein UV cross-linking and GMSA by showing both the specific DNA-protein binding and the protein size. This simplified method is also faster than the method described previously (3) because it can be completed in one day.

\section{REFERENCES}

1.Fisher, P.B., C.S.H. Young, I.B. Weinstein and T.H. Carter. 1981. Tumor promoters alter the temporal program of adenovirus replication in human cells. Mol. Cell. Biol. 1:370380.

2.Manley, J.L., A. Fire, M. Samuels and P.A. Sharp. In vitro transcription: whole cell extract. Methods Enzymol. 101:568-581.

3.Silva, C.M., D.B. Tully, L.A. Petch, C.M. Jewell and J.A. Cidlowski. 1987. Application of a protein-blotting procedure to the study of human glucocorticoid receptor interactions with DNA. Proc. Natl. Acad. Sci. USA 84:1744-1748.

Received 8 July 1996; accepted 5 December 1996.

We are grateful to Drs. Wenyuan Chen and Edwin Saelsmen for carefully reviewing this manuscript. This work was partially supported by a grant from the American Cancer Society, Ohio Branch Inc, to Dr. Calvin B.L. James. Address correspondence to Calvin James, Department of Biological Sciences, Ohio University, Athens, OH 45701, USA. Internet: jamesca@ouvaxa.cats.ohiou.edu

\section{Qiwei Gai, Guang Xu, Timothy Shannon and Calvin B.L. James \\ Ohio University \\ Athens, OH, USA}

\section{Optimized Conditions of PacI and $S w a I$ for Genomic Analysis of $X$. axonopodis pv. vesicatoria by PFGE}

BioTechniques 22:1026-1028 (June 1997)

PacI (5'-TTAATTAA-3') and SwaI $\left(5^{\prime}\right.$-ATTTAAAT- $\left.3^{\prime}\right)$ are two of nine commercially available enzymes with an 8-bp recognition sequence. $P a c I$ and SwaI sites may occur less than once every $10^{6} \mathrm{bp}$ in most genomes that have a $\mathrm{G}+\mathrm{C}$ content over $65 \%$ (5). Both enzymes are useful for fingerprinting and physical mapping of chromosomes, especially for genomes with a $\mathrm{G}+\mathrm{C}$ content in the range of $45 \%-65 \%$ (1). Our digestions of genomic DNA of Xanthomonas axonopodis pv. vesicatoria (Xanthomonas campestris pv. vesicatoria) with these enzymes using recom- mended conditions by the manufacturer were inconsistent. Considering the high cost of these enzymes, inconsistent digestion (Figure 1B) and losses of fragments (4), our goal was to develop a protocol that consistently resolves large fragments of genomic DNA of the bacterium after digestion with $\mathrm{PacI}$ and SwaI by pulsed-field gel electrophoresis (PFGE).

Eighteen different treatments including digestion times, temperatures and amounts of enzymes and digestion buffers, including the manufacturer's recommended buffer and potassium glutamate buffer (KGB) (3), were tested in different combinations to determine the best digestion conditions of genomic DNA of $X$. axonopodis pv. vesicatoria by both PacI (New England Biolabs, Beverly, MA, USA) and SwaI (Boehringer Mannheim, Indianapolis, IN, USA) enzymes. Complete digestions of both enzymes were confirmed by comparing the genome sizes to those obtained with another rare cutting

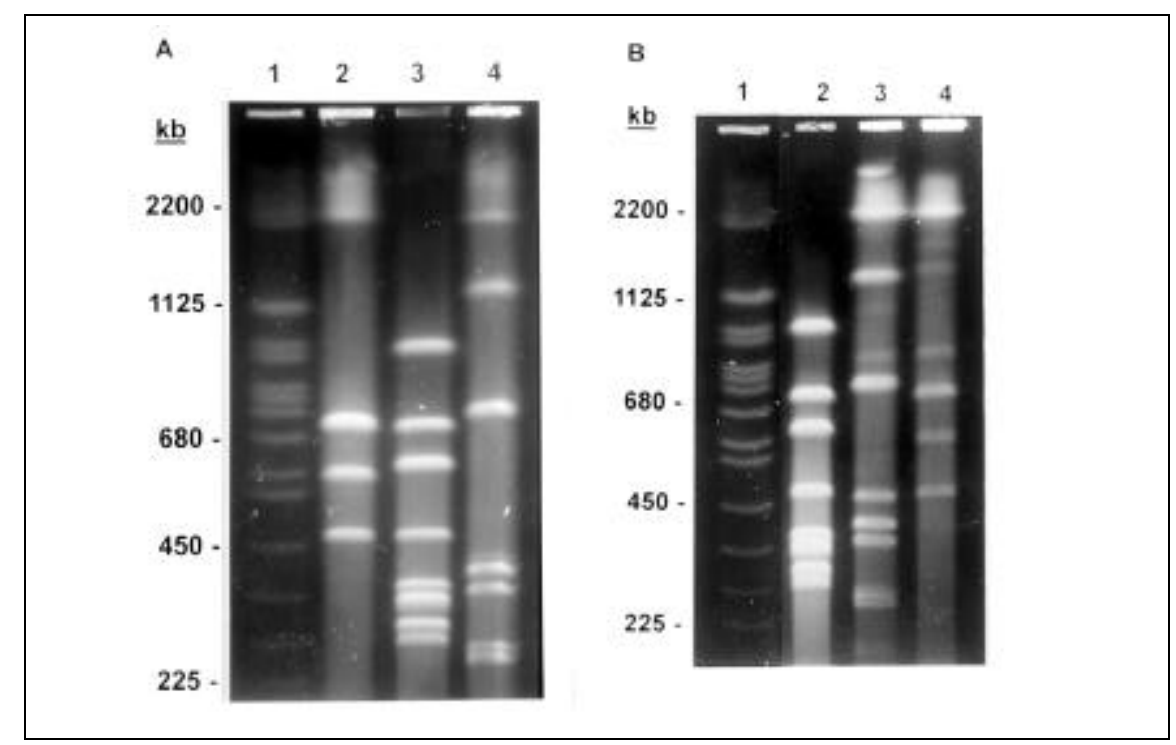

Figure 1. PFGE of restriction endonuclease digests of genomic DNA of $X$. axonopodis pv. vesicatoria XvP26. (A) DNA fragments of X. axonopodis pv. vesicatoria XvP26 digested with PacI, SpeI and SwaI and separated by PFGE in optimized conditions as described in the protocol. Lane 1: DNA size standards of S. cerevisiae chromosomal DNA; lanes 2, 3 and 4: PacI, SpeI and SwaI, respectively. (B) DNA fragments of X. axonopodis pv. vesicatoria XvP26 digested with SpeI, SwaI and PacI in manufacturer's standard conditions and separated by PFGE. The digestions were carried out in a final volume of $100 \mu \mathrm{L}$ in the presence of $18 \mathrm{U}$ of SpeI, $20 \mathrm{U}$ of $S w a \mathrm{I}$ and $5 \mathrm{U}$ of PacI enzymes, and they were kept at $37^{\circ} \mathrm{C}$ overnight, at $25^{\circ} \mathrm{C}$ overnight, at $4^{\circ} \mathrm{C}$ overnight $(16 \mathrm{~h})$, respectively, followed by a 2 -h incubation at $37^{\circ} \mathrm{C}$. Lane 1: DNA size standards of S. cerevisiae chromosomal DNA; lanes 2, 3 and 4: SpeI, SwaI and PacI, respectively. Less intense bands in lanes 3 and 4 represent incomplete digestion of genomic DNA of the bacterium. (A and B) The ramped pulse times were $10-85 \mathrm{~s}$ for $22 \mathrm{~h}$ at $14^{\circ} \mathrm{C}$ and $200 \mathrm{~V}$. The gels were $1 \%$ SeaKem-GTG agarose in $0.5 \times$ TBE buffer. The gels were stained with $0.5 \times$ TBE buffer containing ethidium bromide $(0.5 \mu \mathrm{g} / \mathrm{mL})$ for $30 \mathrm{~min}$ and then destained with $0.5 \times$ TBE buffer for $30 \mathrm{~min}$ after electrophoresis. Then they were photographed over a UV transilluminator with Type 55 Polaroid film (Cambridge, MA, USA). 